\title{
Phenotypic and molecular characterization of Colletotrichum species associated with anthracnose of banana (Musa spp) in Malaysia
}

\author{
M.A. Intan Sakinah, I.V. Suzianti and Z. Latiffah \\ School of Biological Sciences, Universiti Sains Malaysia, Penang, Malaysia \\ Corresponding author: Z. Latiffah \\ E-mail: Lfah@usm.my / latiffahz@yahoo.com
}

Genet. Mol. Res. 13 (2): 3627-3637 (2014)

Received March 13, 2013

Accepted September 26, 2013

Published May 9, 2014

DOI http://dx.doi.org/10.4238/2014.May.9.5

\begin{abstract}
Anthracnose caused by Colletotrichum species is a common postharvest disease of banana fruit. We investigated and identified Colletotrichum species associated with anthracnose in several local banana cultivars based on morphological characteristics and sequencing of ITS regions and of the $\beta$-tubulin gene. Thirty-eight Colletotrichum isolates were encountered in anthracnose lesions of five local banana cultivars, 'berangan', 'mas', 'awak', 'rastali', and 'nangka'. Based on morphological characteristics, 32 isolates were identified as Colletotrichum gloeosporioides and 6 isolates as $C$. musae. C. gloeosporioides isolates were divided into two morphotypes, with differences in colony color, shape of the conidia and growth rate. Based on ITS regions and $\beta$-tubulin sequences, 35 of the isolates were identified as C. gloeosporioides and only 3 isolates as C. musae; the percentage of similarity from BLAST ranged from $95-100 \%$ for ITS regions and $97-100 \%$ for $\beta$-tubulin. $C$. gloeosporioides isolates were more prevalent compared to $C$. musae. This is the first record of $C$. gloeosporioides associated with banana anthracnose in Malaysia. In a phylogenetic analysis of the combined dataset of ITS regions and $\beta$-tubulin using a maximum likelihood method, $C$. gloeosporioides and C. musae isolates were clearly separated into two groups. We concluded
\end{abstract}


that C. gloeosporioides and C. musae isolates are associated with anthracnose in the local banana cultivars and that $C$. gloeosporioides is more prevalent than C. musae.

Key words: Banana; Anthracnose; Colletotrichum gloeosporioides; Colletotrichum musae; ITS regions; $\beta$-tubulin

\section{INTRODUCTION}

Banana belongs to the family Musaceae, which is considered one of the most popular tropical fruits in Malaysia (Abdullah et al., 1990). The production of bananas is ranked second after durian, which is traditionally planted temporarily intercropped with oil palm, rubber and other perennial crops. The most popular varieties of banana for dessert cultivars are 'mas', 'berangan', 'rastali', 'cavendish', and 'embun'.

Anthracnose is one of the most important postharvest diseases of bananas, commonly caused by Colletotrichum musae, which infects wounded green fruits and also ripe fruits (Meredith, 1960; Stover and Simmonds, 1987). C. musae has also been reported causing blossom end rot, crown rot and tip rot of banana (Nazriya et al., 2007). This disease usually occurs during long transportation and storage period with relatively low temperature and high humidity (Thompson and Burden, 1995). Anthracnose of banana is characterized as brown spots, which become sunken lesions with orange or salmon-colored acervuli (Sun, 1988). When the fruits ripen, the disease will be induced by the accumulation of phytoaloxins, which can facilitate the penetration of the fungus (Jeger et al., 1995; Turner, 1995).

Although C. musae is the most common species associated with anthracnose of banana, $C$. gloeosporioides has also been reported to be associated with banana anthracnose (Wijesundera, 1994; Duduk et al., 2009). Most studies related to banana anthracnose in Malaysia have used morphological characteristics to identify Colletotrichum species, which may not be sufficient to confidently use in species delimitation, especially to differentiate closely related species. Moreover, $C$. musae is a member of the $C$. gloeosporioides species complex, which indicates that $C$. musae and $C$. gloeosporiodes are closely related.

Internal transcribed spacer (ITS) regions are useful to define the relationships of Colletotrichum spp within a species complex in phylogenetic analysis (Du et al., 2005; Phoulivong et al., 2010). The $\beta$-tubulin gene can provide a robust tree to support the relationships for species clusters (Shen et al., 2002; Phoulivong et al., 2010). Since Colletotrichum species associated with anthracnose of banana in Malaysia are not well characterized and since most studies have used morphological characteristics for identification, the objective of this study was to isolate and identify Colletotrichum species from anthracnose of banana by using morphological and molecular characteristics and to determine the phylogenetic relationship of Colletotrichum isolates associated with anthracnose of banana by using ITS regions and $\beta$-tubulin gene.

\section{MATERIAL AND METHODS}

\section{Isolation of Colletotrichum isolates}

Thirty-eight Colletotrichum isolates from banana anthracnose were isolated from anthracnose lesions of several local banana cultivars, namely 'mas,' 'berangan,' 'awak, 'nang- 
ka', and 'rastali' (Table 1). The banana fruits were obtained from several markets and farms in the States of Pulau Pinang and Perak, Peninsular Malaysia.

\begin{tabular}{lll}
\multicolumn{2}{c}{ Table 1. Colletotrichum isolates used in this study. } & \\
\hline Isolate & Location & \\
\hline BB1 & Perak & Banana cultivar \\
BB2 & Perak & Berangan \\
BB3 & Pulau Pinang & Berangan \\
BB4 & Pulau Pinang & Berangan \\
BB5 & Pulau Pinang & Berangan \\
BB6 & Pulau Pinang & Berangan \\
BB7 & Pulau Pinang & Berangan \\
BE8 & Pulau Pinang & Berangan \\
BB9 & Pulau Pinang & Mas \\
BR10 & Pulau Pinang & Berangan \\
BR11 & Pulau Pinang & Rastali \\
BB12 & Pulau Pinang & Rastali \\
BB13 & Pulau Pinang & Berangan \\
BA14 & Pulau Pinang & Berangan \\
BA15 & Pulau Pinang & Awak \\
BA16 & Pulau Pinang & Awak \\
BA17 & Pulau Pinang & Awak \\
BA18 & Pulau Pinang & Awak \\
BE19 & Perak & Awak \\
BE20 & Perak & Mas \\
BE21 & Perak & Mas \\
BE22 & Perak & Mas \\
BE23 & Perak & Mas \\
BB24 & Pulau Pinang & Mas \\
BB25 & Pulau Pinang & Berangan \\
BB26 & Pulau Pinang & Berangan \\
BN27 & Pulau Pinang & Berangan \\
BB28 & Pulau Pinang & Nangka \\
BN29 & Pulau Pinang & Berangan \\
BB30 & Pulau Pinang & Nangka \\
BB31 & Pulau Pinang & Berangan \\
BB32 & Pulau Pinang & Berangan \\
BB33 & Pulau Pinang & Berangan \\
BB34 & Pulau Pinang & Berangan \\
BB35 & Pulau Pinang & Berangan \\
BN36 & Pulau Pinang & Berangan \\
BN37 & Pulau Pinang & Nangka \\
BN38 & Pulau Pinang & Nangka \\
\hline & & Nangka \\
\hline
\end{tabular}

Colletotrichum isolates were obtained by using direct isolation and surface sterilization techniques. For direct isolation, conidia from conidial masses from the anthracnose lesions were transferred to potato dextrose agar (PDA) and incubated at $27^{\circ} \pm 1^{\circ} \mathrm{C}$ until visible growth of mycelium was observed. For surface sterilization technique, tissues between infected and healthy areas were cut approximately $5 \times 5 \mathrm{~mm}$ by using a sterile scalpel. The tissue pieces were surface sterilized by dipping in $1 \%$ sodium hypochlorite ( $10 \%$ Clorox) for about 3-5 min and rinsed with distilled water. Four pieces of sterilized tissue were plated on PDA and incubated at $27 \pm 1^{\circ} \mathrm{C}$ until there was visible growth of mycelium from the tissues. For each isolate, single spores were isolated to obtain pure cultures.

Morphological identification of Colletotrichum isolates was performed using the species descriptions by Sutton and Waterston (1970), Mordue (1971), Cannon et al. (2008), Prihastuti et al. (2009), and Su et al. (2011). The shapes and sizes of conidia were determined by measuring 40 random conidia under a light microscope (Olympus BX41 with Soft Imaging System). Culture 
characteristics such as colony color and formation of conidial masses were observed and recorded after 7 days of incubation. To induce appresoria formation, a small amount of mycelium was transferred to a cavity slide, mounted with distilled water and incubated at $27^{\circ} \pm 1{ }^{\circ} \mathrm{C}$ for $24-48 \mathrm{~h}$.

\section{Phylogenetic analysis}

All 38 Colletotrichum isolates were grown on PDA plates with membrane dialysis for 5-7 days. DNA was extracted using the DNeasy Plant Mini Kit (Qiagen, Germany) following the manufacturer protocol. The ITS regions were amplified using the ITS 4 and 5 primers (White et al., 1990), while the $\beta$-tubulin gene was amplified using the Bt2a and Bt2b primers (Glass and Donaldson, 1995). PCR amplification was performed in a $25-\mu \mathrm{L}$ reaction mixture comprising deionized distilled water, $4 \mathrm{mM} \mathrm{MgCl}_{2}$, $5 \mathrm{X}$ PCR buffer, $0.2 \mathrm{mM} \mathrm{dNTP}$ mix (Promega, USA), $0.5 \mathrm{mM}$ of each primer, $0.625 \mathrm{U}$ Taq polymerase (Promega) and 1.6 mM DNA template. PCR amplification for both ITS regions and $\beta$-tubulin gene was performed in a TM Peltier Thermal Cycler Model PTC-100 (MJ-Research, USA). PCR cycles started with an initial denaturation at $95^{\circ} \mathrm{C}$, followed by 34 cycles of denaturation at $95^{\circ} \mathrm{C}$ for $1 \mathrm{~min}, 30 \mathrm{~s}$ annealing at $52^{\circ} \mathrm{C}$ and a 1 -min extension at $72^{\circ} \mathrm{C}$. A final extension for $10 \mathrm{~min}$ at $72^{\circ} \mathrm{C}$ was performed after the cycles ended. Agarose gel electrophoresis $(1 \%)$ was used to detect the PCR product, and the electrophoresis was run for $80 \mathrm{~min}$ at $70 \mathrm{~V}$ and $400 \mathrm{~mA}$. PCR products were purified using the QIAquick PCR Purification kit (Qiagen) according to the manufacturer protocol. The purified PCR products were sent to a service provider for DNA sequencing.

Multiple sequence alignments were performed using MEGA5 (Tamura et al., 2011), and optimized manually. Consensus sequences were compared with sequences in the GenBank database by using Basic Local Alignment Search Tool (BLAST). For phylogenetic analysis, ITS regions and $\beta$-tubulin were analyzed as a combined dataset, which was performed using MEGA5. Gaps were treated as missing data. Maximum likelihood (ML) trees were constructed by using substitution model Tamura-Nei (Tamura and Nei, 1993), inferred from ML heuristic search option with the nearest neighbor interchange (NNI) algorithm. The trees were generated after 1000 bootstraps to estimate the reliability of the tree.

The epitype sequences of ITS regions and $\beta$-tubulin for $C$. gleosporioides and $C$. musae used as comparison are presented in Table 2. Other sequences of ITS regions and $\beta$-tubulin from GenBank were also included in the analysis (Table 2). Two C. trichellum isolates (GU227817 and GU228111), which are members of C. acutatum group were used as outgroup.

\begin{tabular}{|c|c|c|c|}
\hline \multirow[t]{2}{*}{ Species } & \multirow[t]{2}{*}{ Host } & \multicolumn{2}{|c|}{ GenBank accession No. } \\
\hline & & ITS & $\beta$-tubulin \\
\hline C. gloesporioides (epitype) & Citrus & EU371022 & FJ907445 \\
\hline C. gloeosporioides & Mango & DQ454004 & DQ454041 \\
\hline C. gloeosporioides & Mango & DQ454005 & DQ454044 \\
\hline C. gloeosporioides & Citrus & AY376534 & AY376582 \\
\hline C. gloeosporioides & Citrus & AY376532 & AY376580 \\
\hline C. musae (epitype) & Banana & HQ596292 & HQ596280 \\
\hline C. musae & Banana & HQ596293 & HQ596281 \\
\hline C. musae & Banana & HQ596294 & HQ596282 \\
\hline C. trichellum (outgroup) & Hedera helix & GU227817 & GU228111 \\
\hline
\end{tabular}




\section{RESULTS}

\section{Morphological characterization of Colletotrichum species}

On the basis of morphological characteristics, 32 isolates were identified as C. gloeosporioides and 6 isolates as C. musae. C. gloeosporioides isolates could be divided into two morphotypes according to variation in colony color, conidial morphology and growth rate (Figure 1, Table 3). Differentiation between C. gloeosporioides and C. musae isolates was based on the shapes and sizes of the conidia and the growth rate.
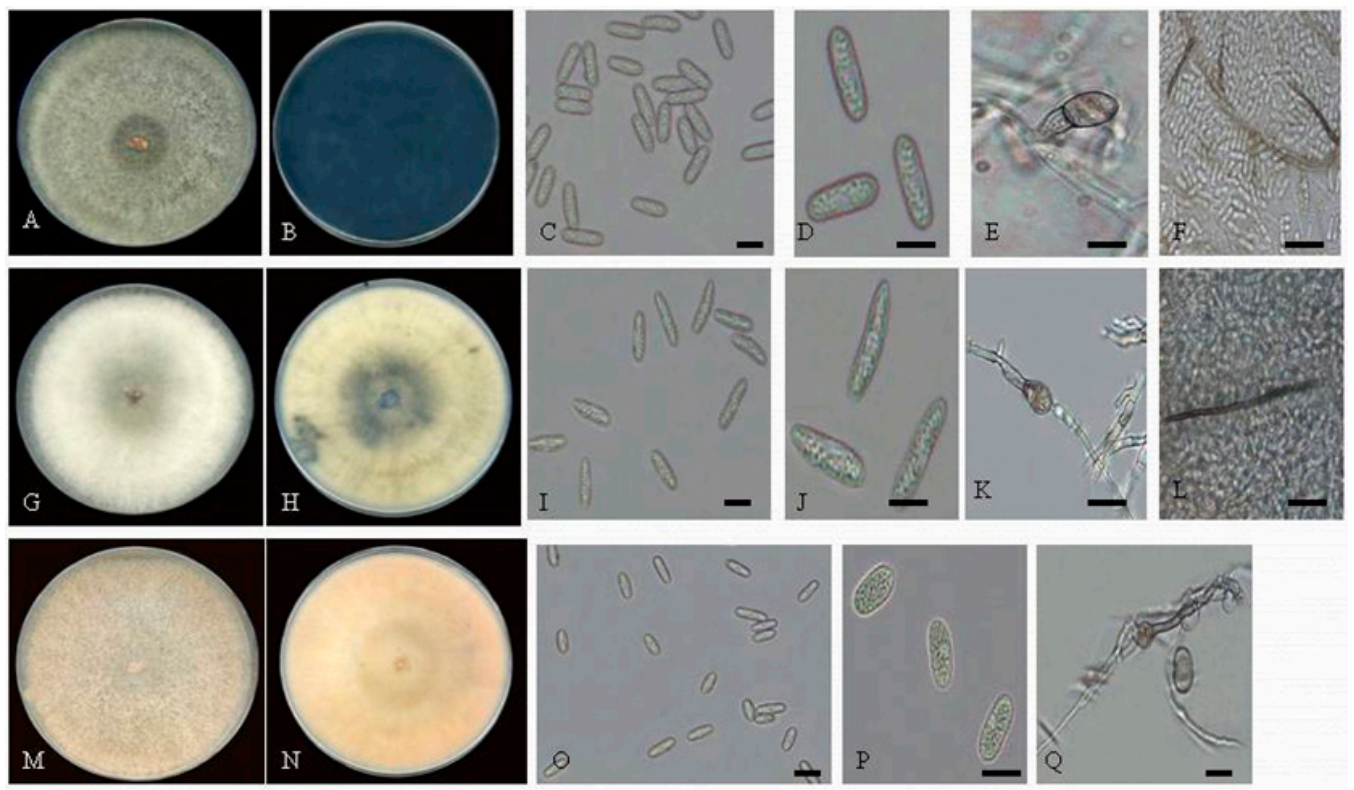

Figure 1. Morphological characteristics of Colletotrichum gloesporioides and C. musae isolated from anthracnose of banana. C. gloeosporioides morphotype 1 (A-F): (A) upper surface, (B) lower surface, (C-D) conidia, (E) appresoria, (F) seta. C. gloeosporioides morphotype 2 (G-I): (G) upper surface, $(\mathbf{H})$ lower surface, (I-J) conidia, (K) appresoria $(\mathbf{L})$ seta $C$. musae $(\mathrm{M}-\mathrm{Q})$ : $(\mathbf{M})$ upper surface, $(\mathbf{N})$ lower surface, $(\mathbf{O}-\mathbf{P})$ conidia, $(\mathbf{Q})$ appresorium $($ Bars $=10 \mu \mathrm{m})$.

Table 3. Morphological characteristics of Colletotrichum gloesporioides and C. musae isolates from anthracnose of banana.

\begin{tabular}{|c|c|c|c|c|c|c|c|}
\hline \multirow[t]{2}{*}{ Species } & \multirow[t]{2}{*}{ Colony color } & \multicolumn{3}{|c|}{ Conidia (mean) } & \multirow[t]{2}{*}{ Appresoria } & \multirow[t]{2}{*}{ Setae } & \multirow{2}{*}{$\begin{array}{r}\text { Growth rate } \\
(\mathrm{cm} / \text { day })\end{array}$} \\
\hline & & Length $(\mu \mathrm{m})$ & Width $(\mu \mathrm{m})$ & Shape & & & \\
\hline $\begin{array}{l}\text { C. gloeosporioides } \\
\text { (morphotype 1) }\end{array}$ & $\begin{array}{l}\text { Gray to moss dark } \\
\text { green }\end{array}$ & $15-16$ & $5-6$ & Cylindrical & $\begin{array}{l}\text { Ovate to obovate } \\
\text { formed }\end{array}$ & $\begin{array}{l}\text { Present in brown color } \\
\text { and slightly swollen at } \\
\text { the base with tapered apex }\end{array}$ & \pm 6.48 \\
\hline $\begin{array}{l}\text { C. gloeosporiodes } \\
\text { (morphotype 2) }\end{array}$ & $\begin{array}{l}\text { Grayish white to } \\
\text { grayish green }\end{array}$ & $16-19$ & $5-6$ & $\begin{array}{l}\text { Fusiform to } \\
\text { slightly } \\
\text { rounded ends }\end{array}$ & $\begin{array}{l}\text { Ovate to obovate } \\
\text { formed }\end{array}$ & $\begin{array}{l}\text { Present in brown color and } \\
\text { slightly swollen at the base } \\
\text { with tapered apex }\end{array}$ & $\begin{array}{l} \pm 5.69 \\
\pm 7.13\end{array}$ \\
\hline C. musae & $\begin{array}{l}\text { White to orangish, } \\
\text { white to gray }\end{array}$ & $13-15$ & $5-7$ & Cylindrical & Irregularly lobed & Absent & \\
\hline
\end{tabular}


C. gloeosporioides morphotype 1 consisted of 17 isolates in which colony appearance was gray to a moss dark-green color. The conidium shape was cylindrical with obtuse ends, and the average size of conidia was $15.0 \times 5.39 \mu \mathrm{m}$. Appresoria were ovate to obovate, and setae were present with brown color and slightly swollen at the base with tapered apex but were absent in some isolates (Figure 1). The growth rate was $\pm 6.48 \mathrm{~cm} /$ day.

C. gloesporioides morphotype 2 comprised 15 isolates, which had colonies appearing grayish white to grayish green. The shape of conidia varied from fusiform to having slightly rounded ends, and the average size of conidia was $16.84 \times 5.68 \mu \mathrm{m}$. Appresoria were ovate to obovate. Setae were present with brown color and slightly swollen at the base with tapered apex but were absent in some isolates (Figure 1). The growth rate was \pm 5.69 $\mathrm{cm} /$ day.

Six isolates were identified as $C$. musae with white to orangish and white to gray colony colors. Conidia were elliptical or cylindrical and the average size was 13.14 x $5.86 \mu \mathrm{m}$. Appresoria were irregularly lobed and lacked setae (Figure 1). The growth rate of C. musae isolates was $\pm 7.13 \mathrm{~cm} /$ day, which was faster than for C. gloeosporioides isolates.

\section{Phylogenetic analysis}

From BLAST, 35 isolates were identified as $C$. gloeosporioides and only 3 isolates as C. musae. The size of ITS regions was $600 \mathrm{bp}$ and the size of $\beta$-tubulin, $500 \mathrm{bp}$. The percentage similarity from BLAST and accession number of the sequences are listed in Table 4 . The percentage similarity obtained from BLAST ranged from 98 to $100 \%$ for ITS regions and from 97 to $100 \%$ for $\beta$-tubulin.

Maximum likelihood trees of combined datasets of ITS regions and $\beta$-tubulin are shown in Figure 2. Both C. gleosporioides and C. musae isolates were grouped in separate clades (clades I and II). C. gloeosporioides isolates from anthracnose of banana were grouped in seven subclades (1-7), and none of the isolates was grouped with the epitype strains (EU371022, FJ907445) or grouped with $C$. gloeosporioides from mango and citrus. Only $C$. gloeosporioides from citrus was grouped with $C$. gloeosporioides epitype strains. C. musae isolates formed a separate clade (clade II) with $82 \%$ bootstrap value and grouped with C. $m u$ sae epitype strains (HQ596292, HQ596280).

\section{DISCUSSION}

The findings from the present study showed that C. gloeosporioides and C. musae were associated with anthracnose of banana, and $C$. gloeosporioides was more prevalent than C. musae. To our knowledge, this is the first documented report of C. gloeosporioides associated with banana anthracnose in Malaysia. The results showed that identification based solely on morphological characteristics can lead to misidentification, since morphological characters are easily influenced by environmental factors such as humidity, temperature and rainfall (Freeman et al., 1998). Therefore, for precise species identification, DNA sequencing data are needed to provide information for species delimitation.

On the basis of morphological characteristics, C. gloeosporioides isolates can be divided into two morphotypes and the descriptions of the isolates in both morphotypes fall within the range of descriptions of C. gloeosporioides by Mordue (1971), Cannon et al. (2008) 
and Prihastuti et al. (2009). Generally, the six C. musae isolates fall within the description of morphological characteristics by Su et al. (2011), except the colony color of several isolates in the present study was white to orangish with floccose aerial mycelium. However, according to the sequences of ITS regions and $\beta$-tubulin, only three isolates (BB9, BN27 and BN29) were identified as C. musae with $99-100 \%$ similarity.

\begin{tabular}{|c|c|c|c|c|c|}
\hline \multirow[t]{2}{*}{ Isolates } & \multirow[t]{2}{*}{ Species name } & \multicolumn{2}{|c|}{ Sequence similarity (\%) } & \multicolumn{2}{|c|}{ GenBank accession No. } \\
\hline & & ITS & $\beta$-tubulin & ITS & $\beta$-tubulin \\
\hline BB1 & C. gloeosporioides & 99 & 99 & JX163228 & JX431527 \\
\hline BB2 & C. gloeosporioides & 100 & 99 & JX163231 & JX431541 \\
\hline BB3 & C. gloeosporioides & 100 & 99 & JX163201 & JX431542 \\
\hline BB4 & C. gloeosporioides & 100 & 100 & JX163217 & JX431543 \\
\hline BB5 & C. gloeosporioides & 98 & 96 & JX163229 & JX431528 \\
\hline BB6 & C. gloeosporioides & 99 & 99 & JX163230 & JX431529 \\
\hline BB7 & C. gloeosporioides & 100 & 99 & JX163215 & JX431544 \\
\hline BE8 & C. gloeosporioides & 100 & 98 & JX163223 & JX431533 \\
\hline BR10 & C. gloeosporioides & 99 & 97 & JX163221 & JX431538 \\
\hline BR11 & C. gloeosporioides & 99 & 96 & JX163219 & JX431539 \\
\hline $\mathrm{BB} 12$ & C. gloeosporioides & 99 & 99 & JX163202 & JX431545 \\
\hline BB13 & C. gloeosporioides & 100 & 99 & JX163203 & JX431546 \\
\hline BB14 & C. gloeosporioides & 100 & 99 & JX163226 & JX431526 \\
\hline BA15 & C. gloeosporioides & 100 & 92 & JX163204 & JX566758 \\
\hline BA16 & C. gloeosporioides & 95 & 99 & JX163225 & JX431547 \\
\hline BA17 & C. gloeosporioides & 99 & 99 & JX163224 & JX431548 \\
\hline BA18 & C. gloeosporioides & 99 & 100 & JX163222 & JX431549 \\
\hline BE19 & C. gloeosporioides & 100 & 99 & JX163205 & JX431550 \\
\hline BE20 & C. gloeosporioides & 99 & 99 & JX163216 & JX431551 \\
\hline BE21 & C. gloeosporioides & 100 & 98 & JX163206 & JX431534 \\
\hline $\mathrm{BE} 22$ & C. gloeosporioides & 100 & 100 & JX163218 & JX431552 \\
\hline BE23 & C. gloeosporioides & 100 & 95 & JX163207 & JX431535 \\
\hline BB24 & C. gloeosporioides & 99 & 99 & JX163227 & JX431553 \\
\hline BB25 & C. gloeosporioides & 99 & 98 & JX163208 & JX431554 \\
\hline BB26 & C. gloeosporioides & 99 & 98 & JX163209 & JX431555 \\
\hline BB28 & C. gloeosporioides & 99 & 99 & JX163210 & JX431531 \\
\hline BB30 & C. gloeosporioides & 99 & 98 & JX163211 & JX431532 \\
\hline BB31 & C. gloeosporioides & 99 & 96 & JX431560 & JX566751 \\
\hline BB32 & C. gloeosporioides & 99 & 99 & JX163220 & JX431556 \\
\hline BB33 & C. gloeosporioides & 99 & 99 & JX163212 & JX431557 \\
\hline BB34 & C. gloeosporioides & 99 & 100 & JX163213 & JX431558 \\
\hline BB35 & C. gloeosporioides & 99 & 99 & JX163214 & JX431559 \\
\hline BN36 & C. gloeosporioides & 99 & 96 & JX431561 & JX566763 \\
\hline BN37 & C. gloeosporioides & 99 & 99 & JX431540 & JX566764 \\
\hline BN38 & C. gloeosporioides & 100 & 99 & JX431562 & JX566758 \\
\hline BB9 & C. musae & 99 & 99 & JX163232 & JX431530 \\
\hline BN27 & C. musae & 99 & 99 & JX163233 & JX431536 \\
\hline BN29 & C. musae & 100 & 97 & JX163234 & JX431537 \\
\hline
\end{tabular}

Although identification using morphological characteristics could lead to misidentification, it is useful for grouping the isolates to their morphotypes as mentioned by Prihastuti et al. (2009). On the basis of phylogenetic analysis of combined datasets as well as an individual dataset (data not shown), C. gloeosporioides and C. musae were clearly separated into different clades. The analysis also showed that location, banana cultivar and morphotype did not contribute to phylogenetic relatedness. The results were similar to those of a study by Rampersad (2011) on papaya anthracnose in which geographical distribution, host cultivar or morphotype was not an indication of the phylogenetic relatedness of the papaya isolates. 


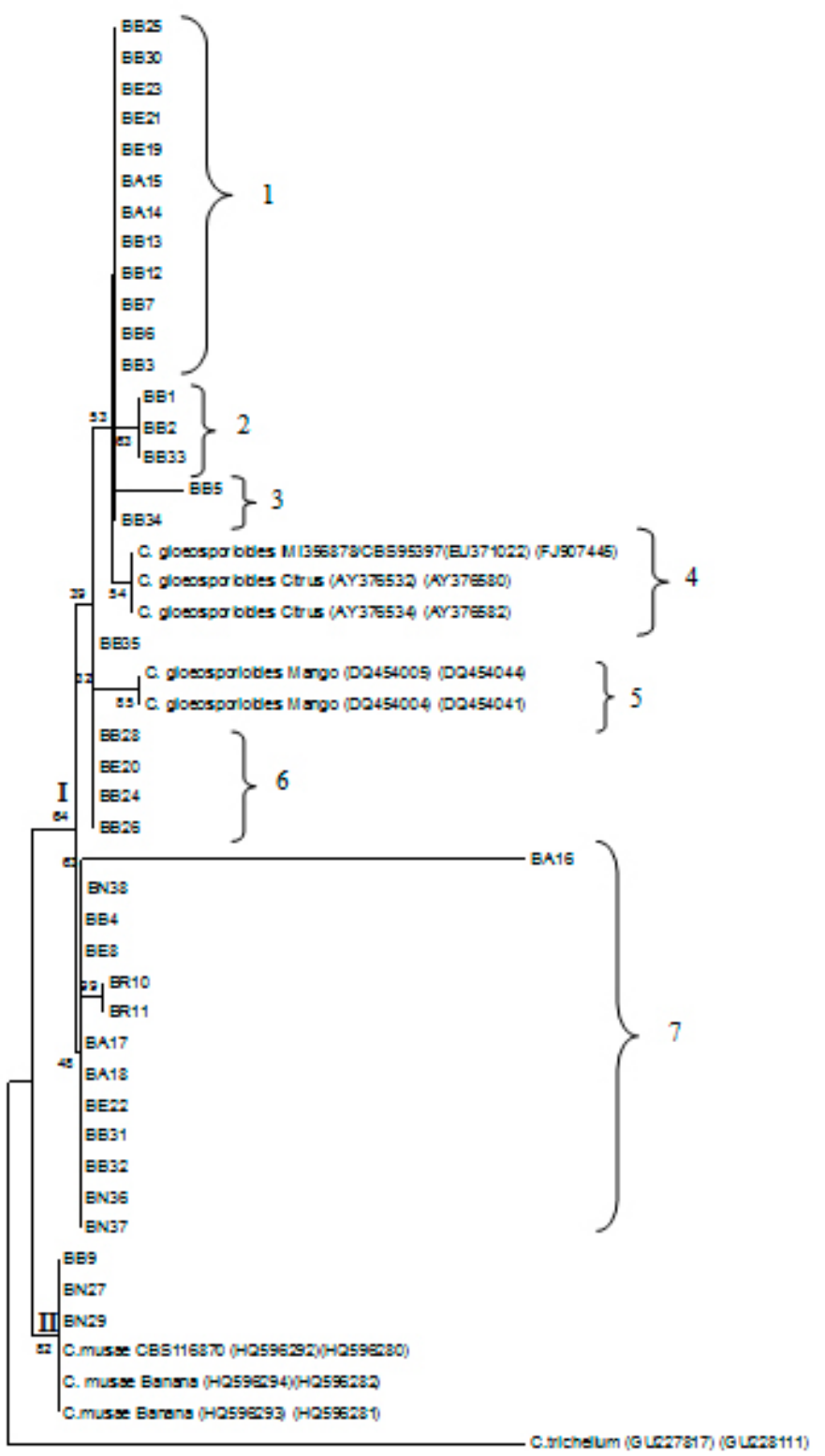

Figure 2. Maximum likelihood showing phylogenetic relationships among Colletotrichum based on ITS regions and $\beta$-tubulin gene using Tamura-Nei substitution model and nearest-neighbor-interchange search options with 1000 bootstrap replicates. Colletotrichum trichellum isolate was the outgroup.

C. gloeosporioides and C. musae are part of the taxa in C. gloeosporioides species complex in which the species in this complex has broad genetic and biological diversity (Damm et al., 2010). C. gloeosporioides is found on a wide variety of fruit crops such as almond, avocado, apple, coffee, banana, guava, mango, and strawberry (Freeman et al., 2000; 
Sanders and Korsten, 2003; Xiao et al., 2004; Photita et al., 2005; Prihastuti et al., 2009). On the other hand, C. musae appears to be specific to Musa spp (Su et al.., 2011). Although $C$. musae was not prevalent in the present study, several studies have shown that C. musae is the most common species associated with anthracnose of banana. In Korea and Saudi Arabia, $C$. musae was associated with anthracnose of imported banana (Lim et al., 2002; Abd-Elsalam et al., 2010). Thangamani et al. (2011) reported that according to morphological and physiological characterization, $C$. musae was pathogenic to banana in India.

The grouping of $C$. gleosporioides isolates into several subclades on the basis of individual dataset (data not shown) and combined datasets, indicated variability, which further confirmed the complexity of the species. Grouping of $C$. gloeosporioides into several subclades suggest that the isolates may represent a sub-population of $C$. gloeosporioides with distinct genetic characters. Similar results were reported by Prihastuti et al. (2009) and Waller et al. (1993) in which C. gloeosporioides on coffee berries showed several distinct genetic and phenotypic species. It was also noted that none of the $C$. gloeosporioides isolates from banana was grouped with the ex-epitype of $C$. gloeosporioides, which could also suggest that the isolates belong to $C$. gloeosporioides-like species, possibly indicating the presence of more than one distinct species. The results of the present study were similar to those of a study by Phoulivong et al. (2010) in which 22 strains of $C$. gloeosporioides from tropical fruits did not cluster with an ex-epitype of C. gleosporioides, indicating the presence of more than one distinct species.

In the present study, three $C$. musae isolates were identified using ITS regions and $\beta$-tubulin sequences and these isolates were grouped with isolates with accession numbers HQ596292 and HQ596280, which confirms that the three isolates were C. musae. This species is a member of the $C$. gloesporioides species complex and has been recognized as a separate species limited to banana or Musa spp (Du et al., 2005). For sequence-based identification of C. musae, ITS sequence is recommended (Weir et al., 2012), which separates the species from other Colletotrichum species.

In the present study, important information was obtained. C. musae was not a common species associated with several types of local banana cultivars, although $C$. musae has been reported to be the most common causal anthracnose of many banana cultivars worldwide (Lim et al., 2002; Abd-Elsalam et al., 2010; Thangamani et al., 2011). C. gloeosporioides is the most prevalent species associated with anthracnose of banana, suggesting the potential of cross-infection to other tropical fruits. Moreover, pathogenic C. gloeosporioides is known to show a mutualistic and commensal association with various plant species. These associations can change under certain conditions (Redman et al., 2001; Photita et al., 2005). Phylogenetic analysis has shown that $C$. gloeosporioides from banana, mango and citrus form separate groups, which supports the hypothesis that $C$. gloeosporioides from tropical fruits may consist of more than one distinct species as reported by Phoulivong et al. (2010).

The findings of this study have an important bearing on the epidemiology of anthracnose disease since different species of Colletotrichum may have different conidial dispersal capacities (Ntahimpera et al., 1999; Rampersad, 2011). Accurate identification of the anthracnose-causing pathogen is also important, since different species of Colletotrichum may vary in their reaction to different types of fungicides (Rampersad, 2011). Sequence analysis using other protein-coding genes should be tested to confirm the existence of more than one distinct species of $C$. gloeosporioides, since this species has wide geographic distribution and host range. 


\section{ACKNOWLEDGMENTS}

Research supported in part by ScienceFund grant from the Ministry of Science, Technology and Innovation (MOSTI), Malaysia (\#305/PBIOLOGY/613225).

\section{REFERENCES}

Abd-Elsalam KA, Roshdy S, Amin OE and Rabani M (2010). First morphogenetic identification of the fungal pathogen Colletotrichum musae (Phyllachoraceae) from imported bananas in Saudi Arabia. Genet. Mol. Res. 9: 2335-2342.

Abdullah H, Pantastico EB, Tirtosoekotja S, Nanthachai P, et al (1990). Status of the Banana Industry in ASEAN. In: Banana: Fruit Development, Postharvest Physiology (Hassan A and Pantastico EB, eds.). Handling \& Marketing in ASEAN, Kuala Lumpur, 1-22.

Cannon PF, Buddie AG and Bridge PD (2008). The typification of Colletotrichum gloeosporioides. Mycotaxon 104: 189204.

Damm U, Baroncelli R, Cai L, Kubo Y, et al. (2010). Colletotrichum: species, ecology and interactions. IMA Fungus. 1: 161-165.

Du M, Schardl CL, Nuckles EM and Vaillancourt LJ (2005). Using mating-type gene sequences for improved phylogenetic resolution of Collectotrichum species complexes. Mycologia 97: 641-658.

Duduk N, Ivanovic M and Duduk B (2009). Morphological, serological and molecular analyses of anthracnose-causing agent on banana fruit. Pestic. Fitomedicina 24: 281-286.

Freeman S, Katan T and Shabi E (1998). Characterization of Colletotrichum species responsible for anthracnose disease of various fruits. Plant Dis. 82: 596-605.

Freeman S, Minz D, Jurkevitch E, Maymon M, et al. (2000). Molecular analyses of Colletotrichum species from almond and other fruits. Phytopathology 90: 608-614.

Glass NL and Donaldson GC (1995). Development of primer sets designed for use with the PCR to amplify conserved genes from filamentous ascomycetes. Appl. Environ. Microbiol. 61: 1323-1330.

Jeger M, Eden GS, Thresh J and Johanson A (1995). Banana Disease. In: Banana and Plantains (Gowen S, ed.). Chapman \& Hall, London, 317-381.

Lim JY, Lim TH and Cha B (2002). Isolation and identification of Colletotrichum musae from imported bananas. Plant Pathol. J. 18: 161-164.

Meredith DS (1960). Studies on Gloeosporium musarum Cke. \& Massee causing storage rots of Jamaican bananas. I. Anthracnose and its chemical control. Ann. Appl. Biol. 48: 279-290.

Mordue JEM (1971). Glomerella cingulata. No. 315. In: CMI Descriptions of Pathogenic Fungi and Bacteria. CAB, Kew.

Nazriya MNF, De Costa DM and Azhaar AS (2007). Genomic variation of Colletotrichum musae morphotypes infecting banana varieties of Sri Lanka. Proc. Peradeniya Univ. Res. Sessions 12: 1-2.

Ntahimpera N, Wilson LL, Ellis MA and Madden LV (1999). Comparison of rain effects on splash dispersal of three Colletotrichum species infecting strawberry. Phytopathology 89: 555-563.

Photita W, Taylor PWJ, Ford R, Hyde DK, et al. (2005). Morphological and molecular characterization of Colletotrichum species from herbaceous plants in Thailand. Fungal Divers. 18: 117-133.

Phoulivong S, Cai L, Chen H, McKenzie EHC, et al. (2010). Colletotrichum gloeosporioides is not a common pathogen on tropical fruits. Fungal Divers. 44: 33-43.

Prihastuti H, Cai L, Chen H, McKenzie EHC, et al. (2009). Characterization of Colletotrichum species associated with coffee berries in Northern Thailand. Fungal Divers. 39: 89-109.

Rampersad SN (2011). Molecular and phenotypic characterization of Colletotrichum species associated with anthracnose disease of papaya in Trinidad. Plant Dis. 95: 1244-1254.

Redman RS, Dunigan DD and Rodriguez RJ (2001). Fungal symbiosis from mutualism to parasitism: who controls the outcome, host or invader? New Phytol. 151: 705-716.

Sanders GM and Korsten L (2003). Comparison of cross inoculation potential of South African avocado and mango isolates of Colletotrichum gloeosporioides. Microbiol. Res. 158: 143-150.

Shen Q, Geiser DM and Royse DJ (2002). Molecular phylogenetic analysis of Grifola frondosa (maitake) reveals a species partition separating eastern North American and Asian isolates. Mycologia 94: 472-482.

Stover R and Simmonds N (1987). Bananas. 3rd edn. Longman, London.

Su YY, Noireung P, Liu F, Hyde KD, et al. (2011). Epitypification of Colletotrichum musae, the causative agent of banana anthracnose. Mycoscience 52: 376-382. 
Sun SK (1988). Postharvest Disease of Subtropical and Tropical Fruits and Their Control. In: Postharvest Handling of Tropical and Subtropical Fruit Crops (Jan Bay-Petersen IO, ed.). Food and Fertilizer Technology Center for the Asian and Pacific Region, Taiwan, 113-122.

Sutton BC and Waterston NW (1970). Colletotrichum musae. CMI Description of Pathogenic Fungi and Bacteria, No. 222. Eastern Press, London.

Tamura K and Nei M (1993). Estimation of the number of nucleotide substitutions in the control region of mitochondrial DNA in humans and chimpanzees. Mol. Biol. Evol. 10: 512-526.

Tamura K, Peterson D, Peterson N, Stecher G, et al. (2011). MEGA5: molecular evolutionary genetics analysis using maximum likelihood, evolutionary distance, and maximum parsimony methods. Mol. Biol. Evol. 28: 2731-2739.

Thangamani PR, Kuppusamy P, Peeran MF, Gandhi K, et al. (2011). Morphological and Physiological Characterization of Colletotrichum musae the causal organism of banana anthracnose. World J. Agric. Sci. 7: 743-754.

Thompson A and Burden O (1995). Harvesting and Fruit Care. In: Banana and Plantains \& Hall (Gowen SR, ed.). Chapman, London, 403-433.

Turner D (1995). The Response of the Plant to the Environment. In: Bananas and Plantains (Gowen SR, ed.). Chapman \& Hall, London, 206-229.

Waller JW, Bridge PD, Black R and Hakiza G (1993). Characterization of the coffee berry disease pathogens, Colletotrichum kahawae sp. nov. Mycol. Res. 97: 989-994.

Weir BS, Johnston PR and Damm U (2012). The Colletotrichum gloeosporioides species complex. Stud. Mycol. 73: 115180.

White TJ, Bruns T, Lee S and Taylor JW (1990). Amplication and Direct Sequencing of Fungal Ribosomal RNA Genes for Phylogenetics. In: PCR Protocols: A Guide to Methods and Application (Innis MA, Gelfand DH, Sninsky JJ and White YJ, eds.). Academic Press, San Diego, 315-322.

Wijesundera RLC (1994). Variation in Colletotrichum gloeosporioides isolates from banana. J. Nat. Sci. Council Sri Lanka 22: 145-150.

Xiao CL, Mackenzie SJ and Legard DE (2004). Genetic and pathogenic analyses of Colletotrichum gloeosporioides isolates from strawberry and noncultivated hosts. Phytopathology 94: 446-453. 